\title{
Hsp90 Antagonist KW-2478
}

National Cancer Institute

\section{Source}

National Cancer Institute. Hsp90 Antagonist KW-2478. NCI Thesaurus. Code C69139.

An agent that targets the human heat-shock protein 90 (Hsp90) with potential antineoplastic activity. Although the mechanism of action remains to be fully elucidated, Hsp90 antag onist KW-2478 appears to inhibit Hsp90, resulting in impaired signal transduction, inhibition of cell proliferation, and the induction of apoptosis in tumor cells. HSP90 is a molecular chaperone that plays a key role in the conformational maturation of oncogenic signaling proteins, such as HER2/ERBB2, AKT, RAF1, BCR-ABL, and mutated p53, as well as many other molecules that are important in cell cycle regulation or immune responses. 